\title{
文部省科学研究助成金による総合研究「VUR研 究班」
}

\section{における非閉塞性 VUR の追跡調查成績について}

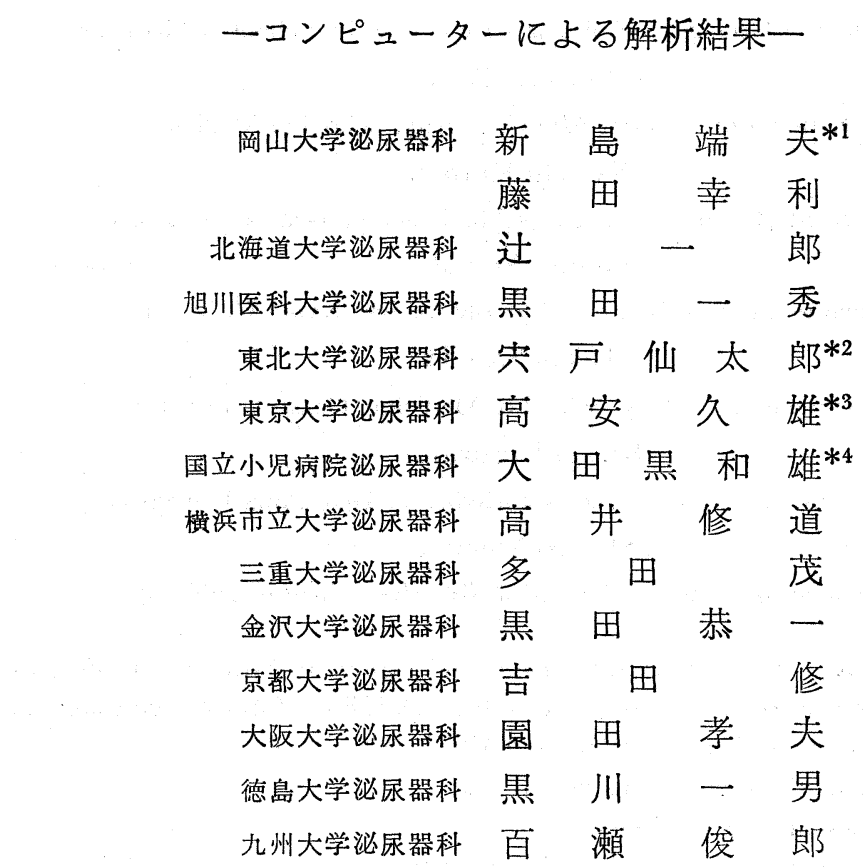

\section{THE RESULTS OF THE RETROSPECTIVE INQUIRIES IN NON- OBSTRUCTIVE VESICO-URETERAL REFLUX}

\author{
-A Computerized Review- \\ Tadao Niijima*1, Yukitoshi Fujita \\ Department of Urology, Okayama University Medical School \\ Ichiro Tsuji \\ Department of Urology, Hokkaido University School of Medicine \\ Kazuhide Kuroda \\ Department of Urology, Asahikawa Medical College \\ Sentaro Shishido*2 \\ Department of Urology, Tohoku University School of Medicine
}

*1 現在 東京大学泌尿器科 $*_{2}$ 現在 仙台社会保険病院

*3 現在 山梨医科大学 $*_{4}$ 現在 名古屋市立大学泌尿器科

*1Present Address: Department of Urology, Faculty of Medicine, University of Tokyo.

${ }^{* 2}$ Present Address: Sendai Social Insurance Hospital.

*3Present Address: Yamanashi Medical School.

*4Present Address: Department of Urology, Nagoya City University School of Medicine. 


\author{
Hisao Takayasu*3 \\ Department of Urology, Faculty of Medicine, University of Tokyo \\ Kazuo Otaguro*5 \\ Department of Urology, National Children's Hospital \\ Shudo Takai \\ Department of Urology, Yokohama City University School of Medicine \\ Shigeru Tada \\ Department of Urology, Mie University, School of Medicine \\ Kyoichi Kuroda \\ Department of Urology, School of Medicine, Kanazawa University \\ Osamu Yoshida \\ Department of Urology, Faculty of Medicine, Kyoto University \\ Takao Sonoda \\ Department of Urology, School of Medicine, Osaka University \\ Kazuo Kurokawa \\ Department of Urology, School of Medicine, Tokushima University \\ Shunro Momose \\ Department of Urology, Faculty of Medicine, Kyushu University
}

Thirteen institutions have received grants from the Japanese Ministry of Education, for comprehensive scientific research into vesico-ureternal reflux (VUR). On this research grant, we have made inquiries into 494 patients with non-obstructive VUR.

A computerized review of these cases was as follows:

A. Analysis of 494 cases (a real number).

1. There were 130 males and 364 females; the male-to-female ratio was $1: 2.8$.

2. The incidence of previous urinary tract infection (UTI) was 76 per cent in males and 88 per cent in females. This difference was caused by adult females under full, sexual life.

3. We grouped the VUR into six grades. Low grade reflux ( $\left.\mathrm{I}_{\mathbf{A}}-\mathrm{IIB}_{\mathbf{B}}\right)$ recovered in approximately 70 per cent and reflux less than III grade comprised more than 90 per cent. It became clear that patients with primary VUR mostly had low grade reflux. Patients with bilateral reflux comprised about 45 per cent of this series. High grade bilateral reflux tended to occur among young male patients.

4. The coefficient of correlation between right and left reflux was $r_{s}=0.63$. This indicated that primary VUR has a high probability of developing bilateral reflux.

5. As far as the coefficient of correlation was concerned, there were no relationship between the grade of reflux and the present illness.

6. The coefficient of correlation between grade of reflux and renal function using intravenous pyelography (IVP) was very low $\left(r_{s}=0.258\right)$, whereas that between grade of reflux and morphological change of the pyelogram was very high $\left(r_{s}=0.662\right)$. Therefore, high grade VUR was associated with morphological change rather than renal function.

B. Analysis of 536 cases (a total number). 42 of this series (494 cases) were included in both groups (group A and B) because surgical repairs were performed after long-term (over 6 months) chemotherapeutic treatment, so that the series amounted to 536 cases.

1. We divided 536 cases into four groups; i.e., group under chemotherapy (group A) 297 cases $(55.4 \%)$, surgically treated group (group B) 194 cases $(36.2 \%)$, non-treated group (group C) 39 cases $(9.3 \%)$ and a fourth group (group D) 6 cases $(1.1 \%)$.

2. A comparative study of the characteristics of A, B and C groups was as follows: Group A 
consisted of relatively young girls with low grade reflux. Group B was made up of a large number of cases with high grade reflux and recurrent UTI. Group C was composed of cases with low grade reflux and few episodes of infection.

3. Surgery for reflux consisted of combined Politano-Leadbetter's method 66 cases $(23.1 \%)$, original Politano-Leadbetter's method 59 cases (20.6\%), Lich-Gregoir's method 58 cases $(20.2 \%)$ and Paquin's method with cuff 49 cases (17.1\%).

C. Analysis of the results in each group.

1. Cures of reflux after each type of treatment were compared. 'Group B had significantly good results, especially grade III and IV groups. This rate differed from other groups to a statistically significant degree $(p<0.001)$. Overall cure rate in group $C$ was 70 per cent, which was better than in group $\mathrm{A}$.

2. Concerning fever attacks, group B had the highest improvement rate, especially the cases with reflux greater than grade II. This was almost the same as the cure rate of reflux.

3. Concerning renal function, IVP results did not show any statistically significant difference among the three groups. However, the changes in pyelographic forms of group B, especially in the grade III, differed significantlly from other groups.

4. In group A, analysis of reflux-cured cases showed the following: These cases almost all have less than grade II reflux. All reflux-cured cases over grade III reflux were younger than ten years old.

5. The cure rate by original Politano-Leadbetter's method was 100 per cent, Paquin's method 94.6 per cent, combined Politano-Leadbetter's method 90.9 per cent and Lich-Gregoir's method 77.8 per cent. Regarding unsuccessful cases of surgery for reflux, combined Politano-Leadbetter's and Hutch's methods failed in nearly all patients under ten years old, while Lich-Gregoir's method failed in adult females.

6. Various antireflux surgeries were compared with regards to IVP; the best procedure was original Politano-Leadbetter's method, while Hutch I method was unsuccessful in about 30 per cent.

\section{緒 言}

昭和 49,50 年の 2 年にわたり，13機関によつて文部省 科学研究助成金による総合研究「膀胱尿管逆流現象に関 する研究」を行らに当り，各機関は独自に，VUR に関 する基礎的, あるいは臨床的研究課題を設定せるほか, 共通の仕事として，以下の如き研究が行われた.

すなわち，VUR が腎孟腎炎と深い関係にあることは， 現在では疑う余地のないことと確認されているが，非閉 塞性 (一次性) VUR の臨床的意義, 治療法の選択基準 の問題, 化学療法剤や投与方法ならびに治療期間に関す る諸問題, さらには, 各種治療法の追跡評価などに関し ては，全く異なつた見解も見られる。これは，僅かな症 例をもとに，問題を論じていることにも起因していると 考兄られる.そこで，この機会を利用して，各機関が保 有している非閉塞性（一次性）VUR 症例を，一定の基 準に捻いて retrospective 飞調査，集計し，種々な方向 から，解析，検討することによつて，少しでも有意な成 績を得んものと企図したわけである.

この目的のために寄せられた非閉塞性，いわゆる， primary VUR の実数は494例で，これを一定の基準のも
とに集計し、コンピューターを利用して統計学的に処理 した.

\section{調查項目ならびに調查票}

調査項目については班会議に招いて審議を重ね, 成る ベく一般的であり，共通した記載が可能な項目にしぼつ た.さらに，記載方法の簡便化を計つた。特に，VUR の grading, 腎機能拉よび腎形態異常の表現方法, VUR 防止手術の術式名ならびに分類については十分に討議を 行い, 決定された。

次に，これに従つて調查票案を作製し各機関にアンケ 一トを求め, 出来上つたものが Table 1 の調査票である

(Table 1). 記載事項はコンピューターによる解析のた めに番号が 付してある．以下主要項目について略記す る.

1）施設名：参加13機関を 2 桁の番号で表わす.

2）患者番号：各機関毎に 3 桁で記入する.

3）年齢・尿路感染症初発年齢：2 析表示とし，1歳 以下は00歳とした。

4）発症に関連すると思われる既往歴：主に女性の結 婚，妊娠歷を調査することを目的としてこの項目を設け 
Table 1 The investigation form

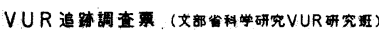

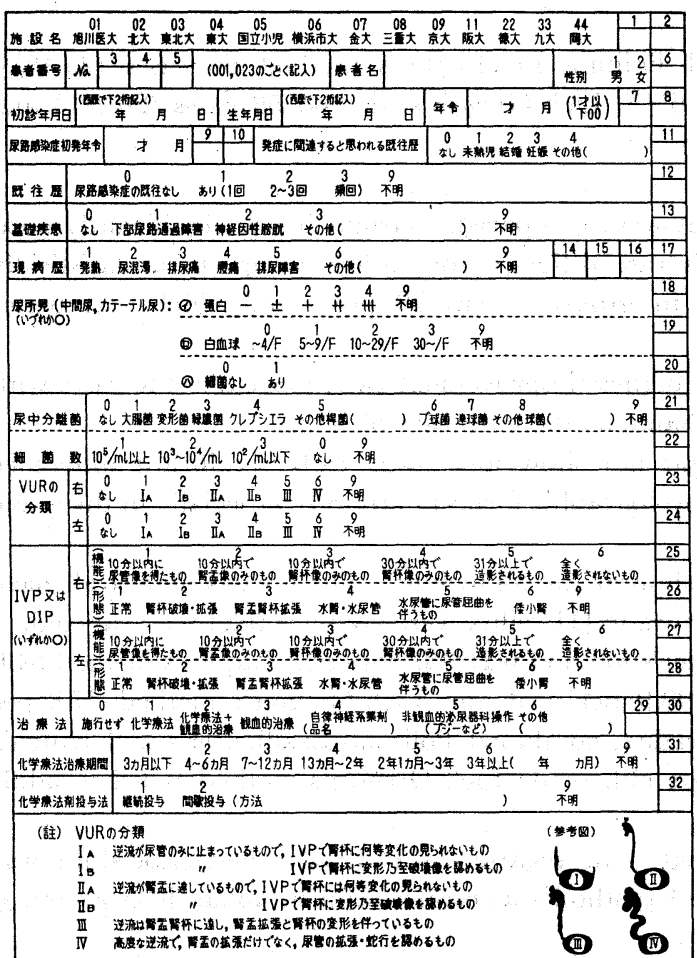

た.

5）基礎疾患：primary VUR を集計することを目標 としたが, Secondary VUR る記載可能とした.

6）現病歴：記載の簡略化のために, 発熱, 尿混濁, 排尿痛, 腰痛を主要項目として取りあげた。

7）尿所見: 蛋白, 白血球, 細菌の種類, 細菌数につ いて調查した。

8）VUR の分類：Cystography および voiding cystography を診断法の原則として，I〜IV度に 分けたが， I , II 度は IVP による腎・尿管の変化を加味して, A, B 2 群とし, 記入の便利なように参考図を付して表示 した.

9）IVP または DIP : 分腎機能ならびに腎形態の、検 索は原則として IVP によることとし，6段階に分類し たが，これに付したコード番号は数字が大きくなるほど 機能・形態共に異常が高度になる。なお，DIP による 記載る可能としたが，集計の際にはこのデーターは形態 的変化の判定にのみ利用した.

10) 治療法: 無治療経過観察群, 長期化学療法施行

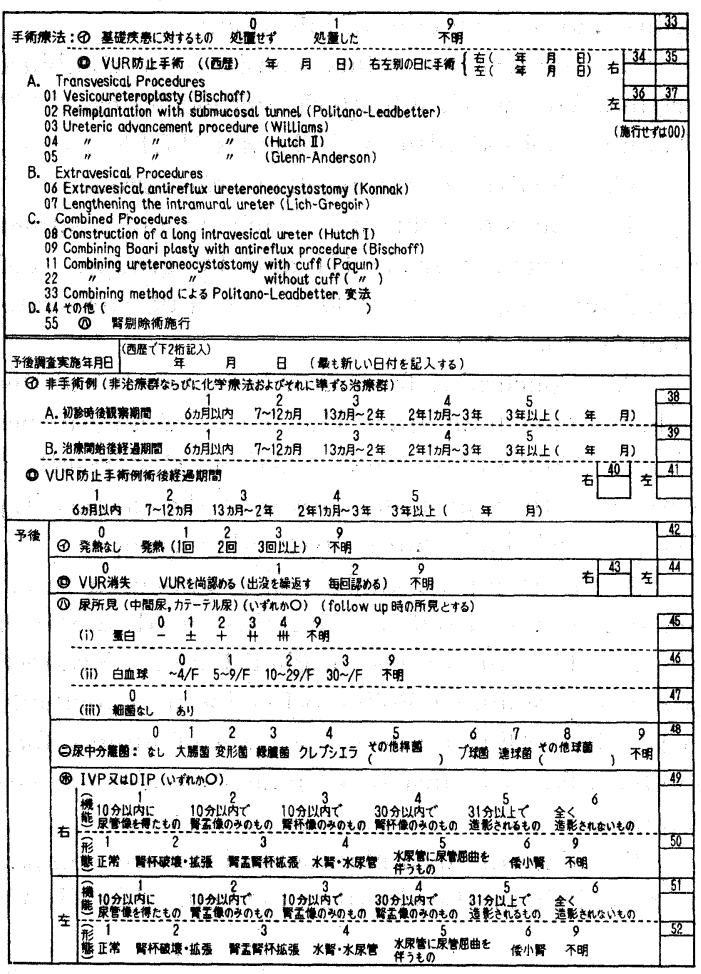

群, 逆流防止手術施行群, 自律神経興奮剂や遮断剂を使 用した群，ブジーなどの非観血的泌尿器科操作を行つた 群，特よび，その他の治療群に分けて，それぞれにコー ド番号を付した.なお，6カ月以上化学療法を行つたあ とで手術に切換えた症例は, 各治療群で登録し, 調查票 は 2 枚記入することにした。 従つてここでは対象は延べ 数536例となる.

11）手術方法：逆流防止手術の分類ならびに記載方法 については，議論が多かつたが，調查票のごとく，transvesical, extravesical, さらに膀脂の内外より行う combined な到達法の 3 群に大別し，個々の術式は人名表示 にしてコード番号をつけた，さらに，記載上の誤解を避 けるため，模式図を原著などから引用して予め配布する などの配慮をした。

12）予後：特に発熱，VUR の消失，尿所見，IVP たはDIP 所見を記入する欄を設けた。

アンケート方式で集めた調查票は，マークシートに写 したのち, 武田薬品工業株式会社の試験解析室に依頼 し て解析を行つた。 


\section{研究協力機関と調查対象}

研究協力機関は Table 2 飞示す13施設である (Table 2).調查対象を多く確保する目的で，特に何年間とは限 定氏寸゙, 可能な限りの症例を記入することとした。

内鮧法，男子130例，女子364例，計494例で, 男女比 は1２８宅あつた。前に述べた如く，6 カ月以上化学 療法范行い，手術療法に切換えた症例が42例あつたの で,てれをそれぞれの治療群に含めると，延数は536例 惊.

Table $2 \quad 13$ institutions and a number of cases

\begin{tabular}{l|r|r|r}
\hline & Male & Female & Total \\
\hline 01 Asahikawa Med.College & 2 & 6 & 8 \\
\hline 02 Hokkaido University & 28 & 44 & 72 \\
\hline 03 Tohoku University & 5 & 4 & 9 \\
\hline 04 University of Tokyo & 9 & 40 & 49 \\
\hline 05 National Children's Hosp. & 28 & 41 & 69 \\
\hline 06 Yokohama City University & 14 & 34 & 48 \\
\hline 07 Kanazawa University & 2 & 39 & 41 \\
\hline 08 Mie University & 4 & 13 & 17 \\
\hline 09 Kyoto University & 7 & 21 & 28 \\
\hline 11 Osaka University & 7 & 26 & 33 \\
\hline 22 Tokushima University & 2 & 15 & 17 \\
\hline 33 Kyushu University & 16 & 49 & 65 \\
\hline 44 Okayama University & 6 & 32 & 38 \\
\hline i. Total & 130 & 364 & 494 \\
\hline
\end{tabular}

\section{結 果}

次の 3 項目について解析を施行した。

1. 研究対象の背景調查

2. 各種治療群の背景調査

3. 各種治療群の追跡調査

以下この順序に従つて, 解析の結果を記述する.

1. 研究対象の背景調查

実数494例について実施した。

a）性・年齢別頻度ならびに分布：女子は男子の約 3 倍に捛よぶが，年代別にみると，Fig. 1 のごとく，20歳 代で26倍もの著しい差が見られるが，20歳以下では性 差は縮まり，10歳以下では1.3〜 2 倍にすぎない（Fig. 1)。これは性的な活動を背景とした女性の尿路感染症の 増加を反映しているものと言えよう。

b) 尿路感染症（以下 UTI と略記）の既往歴と性・ 年齢との関係：男子は $76 \%$ ，女子では $88.1 \%$ と極めて高 率に, UTI との関連が認められた。しかも大部分が再 発性で, VUR とUTI の相関が強く示唆された。

UTI の発生頻度に拮る性差について, Mann Whit-

Fig. 1 Distribution in age and sex (494 cases)

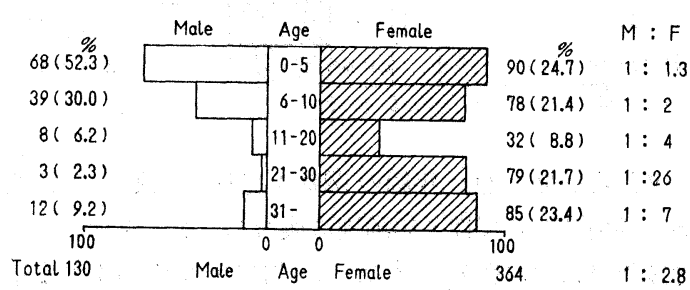

Table 3 History of UTI

\begin{tabular}{|c|c|c|c|c|c|c|c|}
\hline \multicolumn{2}{|l|}{ a } & none & 1 times & $2 \sim 3$ times & $\begin{array}{l}\text { over } \\
4 \text { times }\end{array}$ & Total & Verification \\
\hline \multicolumn{2}{|c|}{ Male (\%) } & $\begin{array}{c}30 \\
(24.0) \\
\end{array}$ & $(11.2)$ & $\begin{array}{c}25 \\
(20.0)\end{array}$ & $\begin{array}{c}56 \\
(44.8) \\
\end{array}$ & 125 & $\begin{array}{r}z_{0}=2.457^{*} \\
(p<0.05)\end{array}$ \\
\hline \multicolumn{2}{|c|}{ Female (\%) } & $\begin{array}{r}42 \\
(11.9) \\
\end{array}$ & $\begin{array}{c}39 \\
(11.1) \\
\end{array}$ & $\begin{array}{c}83 \\
(23.6) \\
\end{array}$ & $\begin{array}{c}188 \\
(53.4) \\
\end{array}$ & 352 & $\begin{array}{c}x_{0}^{2}=9.562^{* * * *} \\
(p<0.001)\end{array}$ \\
\hline \multirow{2}{*}{$0 \sim 10$ years } & Male & 21 & 13 & 22 & 47 & 103 & \multirow{2}{*}{$\mathrm{x}_{0}^{2}=2.462^{\mathrm{NS}}$} \\
\hline & Female & 20 & 19 & 43 & 79 & 161 & \\
\hline \multirow{2}{*}{ Female } & $<20$ yrs. & 22 & 23 & 46 & 101 & 192 & \multirow{2}{*}{$x_{0}^{2}=0.018^{N S}$} \\
\hline & $\geqq 20$ yrs. & 20 & 16 & 37 & 87 & 160 & \\
\hline
\end{tabular}

\begin{tabular}{c|c|c|c|c|c}
\hline & & none & $\begin{array}{c}\text { over } \\
1 \text { time }\end{array}$ & Total & \\
\hline \multirow{3}{*}{ Male } & $<20$ yrs. & 23 & 89 & 112 & $x_{0}^{2}=7.19 * * *$ \\
\cline { 2 - 6 } & $\geqq 20$ yrs. & 7 & 6 & 13 & $(p<0.001)$ \\
\hline
\end{tabular}


ney の検定を施行したところ $5 \%$ 以下， $\chi^{2}$ 検定では 0.1 \%以下の危険率で，有意に女子に高率であることが判明 した.ささらに，性差発現の背景について検討した。その 結果，表示するごとく，10歳以下の男女の間，ならびに 女子の 20 歳未満と 20 歳以上の間には有意な差を見なかつ たが，男子の 20 歳以上で発生頻度が著しく減少すること が見られ，これが全体として性差を生じた原因と言えよ $\zeta$ (Table 3).

c) UTI 初発年䟥：既往歷の初発年齢は Fig. 2 に示 されるごとく，男子で 6 歳以下に集中する傾向が認めら 机，不明を除くと $82.4 \%$ にもよんでいる.女子も 6 歳 以下が $40.4 \%$ と多いが，男子と異なつて 20 代も多く， 2 峰性となうている (Fig. 2).

Fig. 2 Distribution in age and sex on first diagnosis of UTI

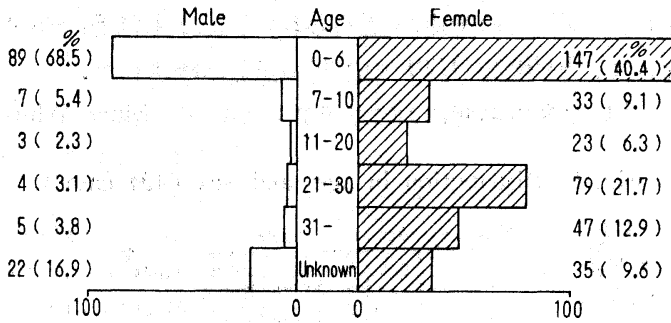

d）現病歷と性・年齢の 関係 : 発熱, 尿混濁, 排尿 痛，腰痛について性・年齢別に検討したが，全体として 性差を見たのは腰痛だけで，0.1\%以下の危険率で女子 に多かつた。くわしく分析した結果，成人女子で腰痛を 訴えたものが多く，有意差はこれで生じたものと判明し た.

e ）尿所見：蛋白尿の出現頻度は低率で，わずか $19 \%$ にすぎなかつた。

f）尿中分離菌：大腸菌が過半数の $58.4 \%$ 占め, と くに女子に多かつた。

g ) VUR の程度 : 両側 VUR を有する症例は220例, 44.5\%に扣よんでいた，症例数で分類する場合，両側例 は高度な方を取つて分類した。 Table 4 亿示すごとく， 約70\%が I A〜 II B の 軽症例であり， III度以下が90\%以 上を占めていた，primary VUR に高度な逆流が 少ない ことを示すものとい光る (Table 4). 表中不明の 1 例は VUR の程度が不明の症例である. 性差でみるに，男子 にIV度が多く, Mann-Whitney の検定でも明らかな有意 差があつた。この原因は Table 5で見られるごとく，
Table 4 Classification of VUR ( 494 cases) (Bil. VUR is classified by advanced side)

\begin{tabular}{c|r|r|r}
\hline Grade & Male (\%) & Female (\%) & Total (\%) \\
\hline$I_{\text {A }}$ & $10(7.7)$ & $41(11.3)$ & $51(10.3)$ \\
\hline$I_{\text {B }}$ & $6(4.6)$ & $16(4.4)$ & $22(4.5)$ \\
\hline$I_{A}$ & $35(26.9)$ & $109(29.9)$ & $144(29.1)$ \\
\hline$I_{\text {B }}$ & $24(18.5)$ & $100(27.5)$ & $124(25.1)$ \\
\hline III & $30(23.1)$ & $80(22.0)$ & $110(22.3)$ \\
\hline IV & $25(19.2)$ & $17(4.7)$ & $42(8.5)$ \\
\hline Unknown & & $1(0.3)$ & $1(0.2)$ \\
\hline Total & 130 & 364 & 494 \\
\hline
\end{tabular}

$z_{0}=2.975^{* *} \quad(p<0.01)$

Table 5 Classification of bilateral VUR (Classified by advanced side)

\begin{tabular}{c|c|c|c|c|c}
\hline Grade & I & II & III & IV & Total \\
\hline $\begin{array}{c}\text { Male } \\
(\%)\end{array}$ & 5 & 26 & 20 & 20 & 71 \\
\hline $\begin{array}{c}\text { Female } \\
(\%)\end{array}$ & $\begin{array}{c}11 \\
(7.4)\end{array}$ & $\begin{array}{c}88 \\
(59.0)\end{array}$ & $\begin{array}{c}42 \\
(28.2)\end{array}$ & $\begin{array}{c}8 \\
(5.4)\end{array}$ & 149 \\
\hline
\end{tabular}

$z_{\circ}=3.547^{* * *} \quad(p<0.001)$

Table 6 Classification of VUR (714 ureters)

\begin{tabular}{c|r|r|r}
\hline Grade & Male (\%) & Female (\%) & Total (\%) \\
\hline$I_{\mathrm{A}}$ & $19(9.5)$ & $72(14.0)$ & $91(12.7)$ \\
\hline $\mathrm{I}_{\mathrm{B}}$ & $9(4.5)$ & $27(5.3)$ & $36(5.0)$ \\
\hline $\mathrm{II}_{\mathrm{A}}$ & $47(23.4)$ & $157(30.6)$ & $204(28.6)$ \\
\hline $\mathrm{II}_{\mathrm{B}}$ & $41(20.4)$ & $131(25.5)$ & $172(24.1)$ \\
\hline III & $49(24.4)$ & $104(20.3)$ & $153(21.4)$ \\
\hline IV & $36(17.9)$ & $21(4.1)$ & $57(8.0)$ \\
\hline Unknown & & $1(0.2)$ & $1(0.1)$ \\
\hline Total & 201 & 513 & 714 \\
\hline
\end{tabular}

男子の 両側例に 高度なVUR が多いことによつている (Table 5).

いつぽう 尿管単位でみても, Table 6 のごとく活ぼ同 傾向を示した (Table 6).

次に, VUR の程度を左右の関係について調べてみた。 Table 7 に示すごとく， $\gamma_{\mathrm{s}}=0.630$ と高い相関係数を示 した (Table 7).

h ）VUR の程度と現病歴の関係：発熱，尿混濁，排 
Table 7 Correlation between right and left reflux

\begin{tabular}{c|c|c|c|c|c|c|c|c|c}
\hline $\begin{array}{c}\text { Right } \\
\text { Left }\end{array}$ & None & $\mathrm{I}_{\mathbf{A}}$ & $\mathrm{I}_{\mathrm{B}}$ & $\mathrm{I}_{\mathrm{A}}$ & $\mathrm{I}_{\mathrm{B}}$ & $\mathbf{I I}$ & $\mathrm{IV}$ & Unknown & Total \\
\hline None & & 21 & 8 & 42 & 28 & 24 & 6 & 1 & 130 \\
\hline $\mathrm{I}_{\mathrm{A}}$ & 20 & 10 & 2 & 4 & 6 & 2 & 1 & & 45 \\
\hline $\mathrm{I}_{\mathrm{B}}$ & 8 & 1 & 3 & 1 & & 1 & & & 14 \\
\hline $\mathbb{I}_{\mathrm{A}}$ & 50 & 9 & 1 & 37 & 12 & 2 & 1 & & 112 \\
\hline $\mathbb{I}_{\mathrm{B}}$ & 34 & 2 & 4 & 5 & 33 & 7 & 2 & & 87 \\
\hline $\mathbb{I I}$ & 24 & 3 & 4 & 3 & 5 & 35 & 3 & & 77 \\
\hline $\mathrm{IV}$ & 8 & & & & 1 & 5 & 15 & & 29 \\
\hline Total & 144 & 46 & 22 & 92 & 85 & 76 & 28 & 1 & 494 \\
\hline
\end{tabular}

$\mathrm{r}_{\mathrm{s}}=0.630$

Table 8 Correlation between grade of reflux and findings of IVP or DIP (by the number of ureter)

\begin{tabular}{c|c|c|c|c|c|c|c}
\hline & \multicolumn{6}{|c}{ Change of renal function } \\
\hline & & 1 & 2 & 3 & 4 & 5 & 6 \\
\hline \multirow{4}{*}{ Grade of VUR } & I & 103 & 9 & & 1 & 2 & \\
\cline { 2 - 9 } & II & 315 & 17 & 14 & 4 & 2 & 7 \\
\cline { 2 - 8 } & II & 104 & 22 & 9 & 3 & 1 & 1 \\
\cline { 2 - 8 } & IV & 33 & 7 & 5 & 3 & & 2 \\
\hline Total & 555 & 55 & 28 & 11 & 5 & 10 \\
\hline
\end{tabular}

$\mathrm{r}_{\mathrm{s}}=0.258$

\begin{tabular}{c|r|r|r|r|r|r|r|c}
\hline \multirow{4}{*}{} & \multicolumn{8}{|c}{ Morpholgical change of the pyelogram } \\
\cline { 2 - 9 } & & 1 & 2 & 3 & 4 & 5 & 6 & Unknown \\
\hline \multirow{4}{*}{ Grade of VUR } & 78 & 28 & 2 & & & 6 & 1 \\
\cline { 2 - 9 } & II & 187 & 112 & 34 & 4 & & 18 & 4 \\
\hline & III & 19 & 54 & 37 & 17 & & 12 & 1 \\
\cline { 2 - 9 } & IV & & 11 & 10 & 10 & 13 & 6 & \\
\hline Total & & 284 & 194 & 83 & 31 & 13 & 42 & 6 \\
\hline
\end{tabular}

$r_{S}=0.662$

㽷痛などの有無とVUR の程度との順位相関を調べた が, $\gamma_{\mathrm{s}}=0.2$ 以上を示すものはなく，相関なしと判定し た.

i ) 腎責撮影所見とVUR の程度との関係：尿管単位 について両者の関係を調べた. Table 8 に示した数字は 先に述べたごとく 1 が正常を, また 6 が病的変化の最も 強いことをあらわしている (Table 8).な㭴形態につ いては DIP の所見も含めたので, その例数が多くなつ ている. 順位相関は腎機能で $\gamma_{\mathrm{s}}=0.258$ と低い. 形態で は $\gamma_{\mathrm{s}}=0.662$ と当然ながら非常に高い值であつた。

2. 各種治療群の背景調查

治療法によつて長期化学療法施行群（以下化療群また はA 群と略記), 逆流防止手術施行群（以下手術群また はB 群と略記), 無治療経過観察群 (以下無治療群また はC 群と略記) お.よびその他の治療群（以下 D 群と略 記）の4 群に分计た。はじめに述べたごとく，6 カ月以
Table 9 Methods of the treatment

\begin{tabular}{c|c|c|c|}
\hline & Male (\%) & Female (\%) & Total (\%) \\
\hline Chemotherapy group (A) & $70(50.0)$ & $227(57.3)$ & $297(55.4)$ \\
\hline Surgically treated group (B) & $52(37.1)$ & $142(35.9)$ & $194(36.2)$ \\
\hline Non- treated group (C) & $17(12.1)$ & $22(5.6)$ & $39(7.3)$ \\
\hline Fourth group (D) & $1(0.7)$ & $5(1.3)$ & $6(1.1)$ \\
\hline Total & 140 & 396 & 536 \\
\hline
\end{tabular}

$\mathrm{x}_{0}^{2}=7.194 \quad(\mathrm{p}<0.05)$

上化学療法を実施したのち手術に切り換克た症例を複数 に登録したので延536例になつた。

各群の例数は A 群が最も多くて297例 $(55.4 \%), \mathrm{B}$ 群 194例 (36.2\%), C群39例 (7.3\%), D群 6 例 (1.1\%) の順となつている. D 群は極めて少数で他の群との比較 は無意味であり，以後の検討からは全く除外した（Table 9).

以下 3 群の等質性について分析したが，腎摘除術施行 群はB群の中でも特殊であり, B 群についての解析の際 には除外した。

a) 性・年齢：A，B間に性差はないが，C群はA， B両群に比して男子が有意に $(\mathrm{p}<0.05)$ 多かつた。年 路分布を累積百分率でグラフにすると, Fig. 3でみられ るごとく，A，C群はB 群に比し若年層が多い（Fig. 3). Kruskal-Wallis の検定では, A 群対 B 群 $(\mathbf{p}<0.05)$, $\mathrm{A}$ 群対 $\mathrm{C}$ 群批よび $\mathrm{B}$ 群対 $\mathrm{C}$ 群 $(\mathrm{p}<0.01)$ の間に有意差 を認めた。

Fig. 3 Treatments and distribution in age. (Cummulative percentage)

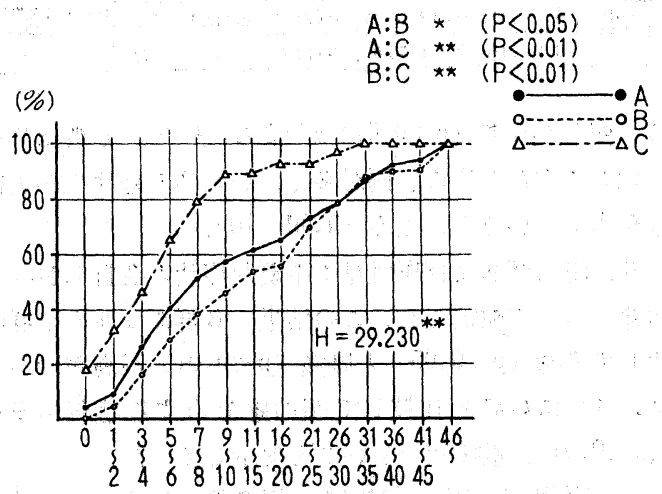

b ) 症状初発年榆：前出の診断時年龄に比し，C群は 若年層一の偏りが一層著明である. 推計学的には, A 群 対 C 群， B 群対 C 群の間は $1 \%$ 以下の危険率で有意差を 見たが，A群とB群に差は認めなかつた (Fig. 4).

c) UTI の既往：Table 10亿示すごとく, 各群の間に 
Fig. 4 Treatments and age on first diagnosis of UTI. (Cummulative percentage)

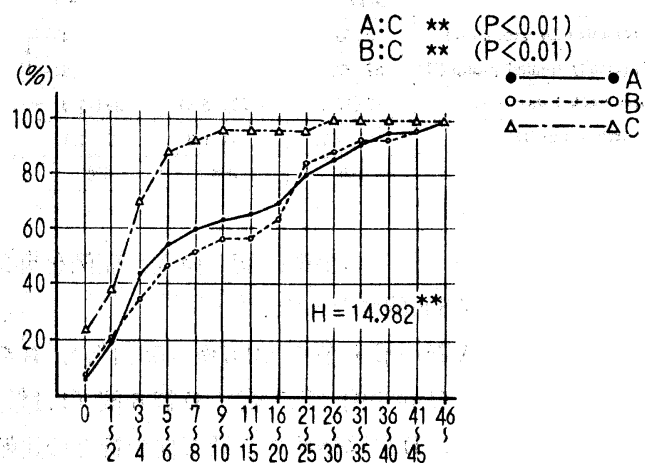

Table 10 UTI history of each group

\begin{tabular}{c|c|c|c|c|c}
\hline & $\begin{array}{c}\text { Over } \\
4 \text { times }\end{array}$ & $2 \sim 3$ & 1 & None & Total \\
\hline $\mathrm{A}$ & $145(50.0)$ & $66(22.8)$ & $38(13.1)$ & $41(14.1)$ & 290 \\
\hline $\mathrm{B}$ & $120(65.2)$ & $35(19.0)$ & $13(7.1)$ & $16(8.7)$ & 184 \\
\hline $\mathrm{C}$ & $7(18.9)$ & $12(32.4)$ & $4(10.8)$ & $14(37.8)$ & 37 \\
\hline
\end{tabular}

Kraskal- Wallis test, $\mathrm{H}=33.598^{* *} \quad(\mathrm{p}<0.001)$

Table 11 Classification of VUR in each group

\begin{tabular}{|c|c|c|c|c|c|c|c|}
\hline & & I & II & III & Iv & Total & $\begin{array}{l}\text { Kruskal-Wallis } \\
\text { test }\end{array}$ \\
\hline & A & $42(24.1)$ & $103(59.2)$ & $25(14.4)$ & $4(2.3)$ & 174 & \\
\hline VUP & B & $6(6.6)$ & $45(50.0)$ & $28(31,1)$ & $11(12.2)$ & 90 & $\begin{array}{r}\mathrm{H}=41.733 \\
(p<0.001\end{array}$ \\
\hline & $c^{\prime}$ & $32.0)$ & $14(56.0)$ & $(12.0)$ & 0 & 25 & \\
\hline & A & $46(18.8)$ & $138(56.6)$ & $48(19.7)$ & $12(4.9)$ & 244 & \\
\hline & B & $3(11.0)$ & $82(39.4)$ & $67(32.2)$ & $36(17.3)$ & 208 & $(p<0.001)$ \\
\hline & c & $4(14.3)$ & $21(75.0)$ & (10.7) & 0 & 28 & \\
\hline
\end{tabular}

は，明らかな差（p<0.01）が認められた。C群はB 群 に比して“なし”の症例が多く、いわゆる軽症例が大部 分を占めていると言える (Table 10).

d）現病歴および尿所見：主要な症状の各群におけす 頻度について検定した.この結果， B 群には他の 2 群に 比して発熱 $(\mathrm{p}<0.05)$ と腰痛 $(\mathrm{p}<0.01)$ が高率であつ た。ささにC群と比較して蛋白尿を有する症例が多く $(\mathrm{p}<0.01)$, 重症例の多いことを示していた.

e ) VUR の程度 : 偏側例, 両側例に分けた上で尿管 単位で比較した (Table 11). 偏側群・両側群共に B 群 飞高度な VUR が有意に多く $(\mathrm{p}<0.001)$ ，これは当然 の結果である。な拈，C群にはIV度のVUR は全く認 めなからた.

f ) 化学療法実施期間之薬剤投与形式：Fig. 5亿示す
Fig. 5 A group : Follow-up periods and methods of medication

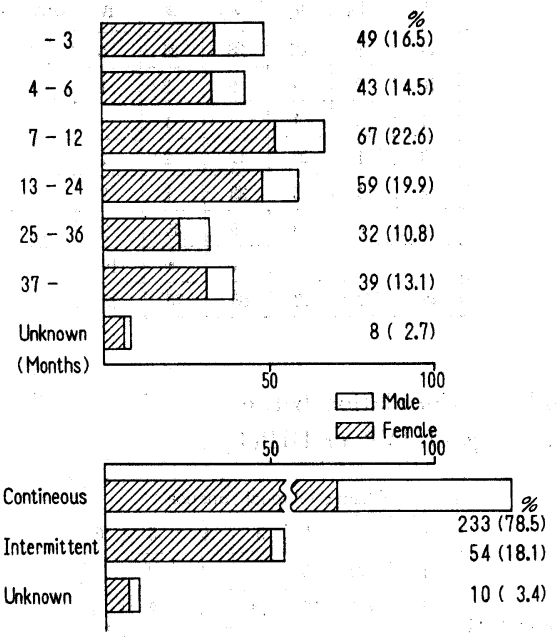

Table 12 Operative procedures (287 ureters)

\begin{tabular}{|c|c|c|}
\hline & $\begin{array}{l}\text { Number of } \\
\text { operations (\%) }\end{array}$ & Total (\%) \\
\hline A. Transvesical procedures & - & \multirow{6}{*}{$74(25.8)$} \\
\hline 01 Bischoff & $3(1.0)$ & \\
\hline 02 Politano-Leadbetter & $59(20.6)$ & \\
\hline 03 Williams & $4(1.4)$ & \\
\hline 04 Hutch II & $6(2.1)$ & \\
\hline 05 Glenn- Anderson & $2(0.7)$ & \\
\hline B. Extravesical procedures & & \multirow{3}{*}{$58(20.2)$} \\
\hline 06 Konnak & & \\
\hline 07 Lich-Gregoir & $58(20.2)$ & \\
\hline C. Combined procedures & & \multirow{6}{*}{$138(48.1)$} \\
\hline 08 Huth I & $17(5.9)$ & \\
\hline 09 Bischoff & 0 & \\
\hline 11 Paquin (with cuff) & $49(17.1)$ & \\
\hline 22 Paquin (without cuff) & $6(2.1)$ & \\
\hline 33 Combined Politano- Leadbetter & $66(23.1)$ & \\
\hline D. 44 Other antireflux procedures & $2(0.7)$ & $2(0.7)$ \\
\hline E. 55 Nephrectomies & t. & $15(5.2)$ \\
\hline
\end{tabular}

ごとく，66\%が 7 カ月以上にわたる治療を，また，約 80 \%が継続的な投与を受けていた (Fig. 5).

g ）VUR 防止手術の種類と年齢分布：術式は大きく 3 群に分けられ，各術式にはコンピューター用のコード 番男を 2 桁の数字で付した. 以後術式の表示はこの番号 を使用している (Table 12).

287尿管に対して手術を施行したが，このうち15例，

$5.2 \%$ には腎摘除術が施行されている.

逆流防止手術の行われた272尿管にひついて 到達路をみ 
Fig6 Distribution in age of major antireflux surgeries.

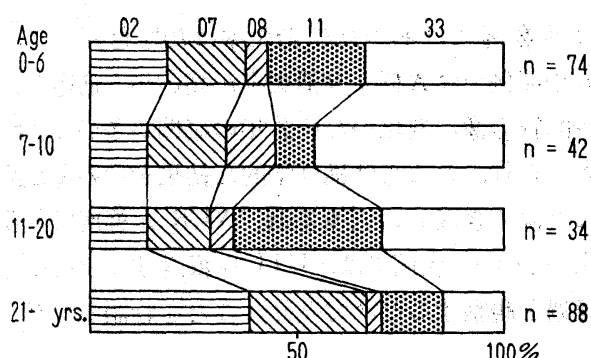

50 $100 \%$
Е02 Politano-Leadbetter
जIV 07 Lich-Gregoir
DZ 08 Hutch I
ming 11 Paqin with cuff
$\square 33$ Combined Politano-Leadbetter

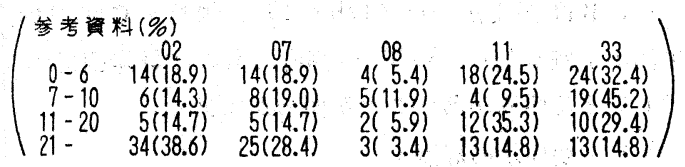

ると， combined なものが138尿管50.7\%と最も多く， transvesical は74尿管 $27.2 \%$, extravesical は58尿管 21.3 \%で，その他は 2 例 $0.8 \%$ となつていた.

手術方法別では, Politano-Leadbetter 変法 (33) 66 尿管 $(23.1 \%)$ ，同原法（02）59尿管 $(20.6 \%)$ ，LichGregoir 法（07）58尿管 $(20.2 \%)$, Paquin with cuff 法
（11） 49尿管 (17.1\%)，Hutch I法（08） 17尿管 (5.9 \%)が主なものである.

これら主な手術の年齡分布は Fig. 6 に示されるごと くで, 7 10歳で Politano-Leadbetter 変法が， また21 歳以上で同原法が比較的多く実施される傾向がみられた (Fig. 6). 到達路よりすると，年少者の過半数が combined method で行われているが，成人では3つの到達 路が注同率に実施されていると言兄る。

h) 手術群の術後観察期間：7 月以上観察されたも のが73\%，13カ月以上が52\%を占めていた。

i ）無治療群の観察期間： 6 カ月未満はわずか $5 \%$ で，男女共 3 年以上観察されたものが $61.5 \%$ に特よん でいた.

j) 小括：以上を分析してみると, 化療群, 手術群, 無治療群の 3 群間には明らかに背景の差が見られた。す なわち，手術群はVUR が高度でUTI の既往を有す る重症例が多く，無治療群と化療群は比較的若年者て VUR も軽度な症例が主体をなしているが，若年者の割 合は無治療群が高からた。

3. 各種治療群の追跡調査

a ) VUR の消長：治療法別に VUR の経過を尿管数 で検討した (Table 13).

Grade I ではA群を除き症例が少ないが，B，C両群 の間には消失率で差がなく，A群と B 群の間に有意差

Table13 VUR after verious treatments. (by the number of ureter)

\begin{tabular}{|c|c|c|c|c|c|c|}
\hline \multirow[b]{2}{*}{ Grade } & \multirow[b]{2}{*}{ Treatment } & \multicolumn{3}{|c|}{ Reflux after treatment } & \multirow[b]{2}{*}{ Total } & \multirow[b]{2}{*}{ Test } \\
\hline & & $\begin{array}{l}\text { Eliminated } \\
(\%)\end{array}$ & $\begin{array}{c}\text { Diminished } \\
(\%)\end{array}$ & $\begin{array}{c}\text { Unchanged } \\
(\%)\end{array}$ & & \\
\hline \multirow{3}{*}{ I } & A & $35(43.7)$ & $25(31.2)$ & $20(25.0)$ & \multirow{3}{*}{$\left.\begin{array}{c}80\lrcorner \\
25 \stackrel{*}{\lrcorner} \\
9 \stackrel{*}{\lrcorner}\end{array}\right]$} & \multirow{3}{*}{$\begin{array}{l}\mathrm{H}=6.785^{*} \\
(\mathrm{p}<0.05)\end{array}$} \\
\hline & B & $18(72.0)$ & $4(16.0)$ & $3(12.0)$ & & \\
\hline & $\mathrm{C}$ & $7(77.8)$ & 0 & $2(22.2)$ & & \\
\hline \multirow{3}{*}{ II } & A & $51(25.6)$ & $41(20.6)$ & $107(53.8)$ & \multirow{3}{*}{$\underset{121\lrcorner * *}{199}\rceil_{* * *}$} & \multirow{3}{*}{$\begin{array}{c}\mathrm{H}=109.080^{* * *} \\
(\mathrm{p}<0.001)\end{array}$} \\
\hline & B & $104(86.0)$ & $4(3.3)$ & $13(10.7)$ & & \\
\hline & C & $21(72.4)$ & $6(20.7)$ & $2(6.9)$ & & \\
\hline \multirow{3}{*}{ III } & A & $10(15.4)$ & $5(7.7)$ & $50(76.9)$ & \multirow{3}{*}{$91 \stackrel{* * *}{7}$} & \multirow{3}{*}{$\begin{array}{c}H=97.965^{* * *} \\
(p<0.001)\end{array}$} \\
\hline & B & $82(90.1)$ & $5(5.5)$ & $4(44)$ & & \\
\hline & C & 0 & $1(20 ; 0)$ & $4(80,0)$ & & \\
\hline \multirow[t]{2}{*}{ IV } & A & $2(13.3)$ & 0 & $13(86.7)$ & 15 & \multirow{2}{*}{$Z_{(p<0.001)}$} \\
\hline & B & $36(80.0)$ & 0 & $9(20.0)$ & 45 & \\
\hline
\end{tabular}

$\mathrm{H}=$ Kruskal- Wallis test

$\mathrm{Z}_{0}=$ Mann-Whitney test 
Table 14 VUR after verious treatments (over 7 months follow-up cases)

\begin{tabular}{|c|c|c|c|c|}
\hline \multirow{2}{*}{\multicolumn{2}{|c|}{ Treatment }} & \multicolumn{2}{|c|}{ Reflux after treatment } & \multirow[b]{2}{*}{ Total } \\
\hline & & $\begin{array}{c}\text { Eliminated } \\
(\mathscr{O})\end{array}$ & $\begin{array}{l}\text { Unchanged } \\
(\mathscr{6})\end{array}$ & \\
\hline \multirow{4}{*}{ Jrade II } & A & $39(26.7)$ & $107(73.3)$ & \multirow{3}{*}{ 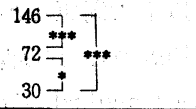 } \\
\hline & B & $55(76.5)$ & $17(23.6)$ & \\
\hline & C & $22(73.3)$ & $8(26.7)$, & \\
\hline & & & & $\begin{array}{c}\mathrm{A}: \mathrm{B} \mathrm{X}^{2}=121.62^{* * *} \\
\mathrm{~A}: \mathrm{C}\left(\mathrm{X}^{2}=0.001\right) \\
\mathrm{B}: \mathrm{C}\left(\mathrm{p}<\mathrm{X}^{2}=50.001\right) \\
\left(\mathrm{p}<0.052^{* * *}\right. \\
(\mathrm{p}<0.05)\end{array}$ \\
\hline \multirow{4}{*}{ irade III } & A & $10(17.2)$ & $48(82.8)$ & \multirow{3}{*}{$\begin{array}{l}58 \neg \\
76 \text { *** } \\
6\end{array}$} \\
\hline & B & $70(92.1)$ & $6(7.9)$ & \\
\hline & C & & $6(100.0)$ & \\
\hline & & & & $\begin{array}{c}\mathrm{A}: \mathrm{B} \mathrm{X}^{2}=60.84^{* * * *} \\
(\mathrm{p}<0.001)\end{array}$ \\
\hline
\end{tabular}

$(\mathrm{p}<0.05)$ が認められた.

Grade IIではA群とB群，A群とC 群の間にそれぞれ 意な差 $(\mathrm{p}<0.01)$ がみられ，ここではB群とC 群と

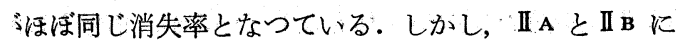

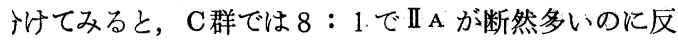
てて，B群は $1 ： 2 て ゙ I \mathrm{~B}$ が多く，結果が同じでも背景 今異なつていた。

Grade III，IVになるとB群の成績が目立つて良く，逆 二A群はわずか $13 〜 15 \%$ の消失率に止まつていて, 高度
なVURに和ける手術療法の必要性を裏付ける成績であ つた.

C 群は少数例ではあつたが 消失率は70\%を示した: I , II 度の症例ではA 群より消失率が高いが,- 前述のご とく比較的腎盎像に变化のない若年の症例が多いことが 原因と考えられ，ここでは推計学的な結果をそのまま評 価することはできない。とむあれ，VUR が軽度で上部 尿路変化の乏しい症例では，UTI を絽返すことのない 場合，経過を観察するだけで充分なことを物語るものと いえる.

次に，7 カ月以上にわたる長期観察例について消長を みた. 少数例なのでII, III度のすのを尿管単位で検討し たが，Table 14のごとく，いずれもB群の成績がよく， II 度にあつては，B 群とC 群の間にも $5 \%$ 以下の危険率 ながらB群がよかつた (Table 14)。度のC群には消 失例が 1 例もなく, VUR が高度なものは経過観察だけ で消失する望みが薄いことが明らかである。

b) 主要症状の経過 :

i) 発熱: 改善の有無について調べた (Table 15). I 度では推計学的に有意差をみないが，I度以上では B 群がA群に比して明らかに改善率が高い，この傾向は7 カ月以上の長期観察グループでも同じであり，VUR の 消長とほぼ一致した結果であつた。

Table 15 Fever after various treatments

\begin{tabular}{|c|c|c|c|c|c|}
\hline Grade & Treatment & Improved & $\begin{array}{l}\text { Unichanged } \\
\text { or Deterior- } \\
\text { ated (\%) }\end{array}$ & Total & $\mathrm{X}^{2}$ test \\
\hline \multirow{3}{*}{ I } & A & $26(66.7)$ & $13(33.3)$ & \multirow{3}{*}{$\begin{array}{l}39 \\
6\end{array}$} & \multirow{3}{*}{$\mathrm{X}^{2}=2.40^{\mathrm{NS}}$} \\
\hline & B & $5(83.3)$ & $1(16.7)$ & & \\
\hline & $\mathrm{C}$ & $3(75.0)$ & $1(25.0)$ & & \\
\hline \multirow{3}{*}{ II } & A & $85(59.4)$ & $58(40.6)$ & \multirow{3}{*}{$72 \stackrel{143-\frac{* * *}{\mathrm{NS}}}{16 * *}$} & \\
\hline & B & $56(77.8)$ & $16(22.2)$ & & \\
\hline & $\mathrm{C}$ & $13(81.3)$ & $3(18.7)$ & & \\
\hline & & & & & $\begin{array}{l}\mathrm{A}: \mathrm{B} \mathrm{X}^{2}=34.36^{* * *} \\
(\mathrm{p}<0.001)^{2} \\
\mathrm{~A}: \mathrm{C} \mathrm{X}^{2}=9.64^{* *} \\
\left.\mathrm{~B}: \mathrm{(p} \mathrm{X}^{2}=3.01\right) \\
\end{array}$ \\
\hline \multirow{3}{*}{ III } & A & $28(58.3)$ & $20(41.7)$ & \multirow{3}{*}{$487 *$} & \multirow{3}{*}{$\mathrm{X}^{2}=25.87^{* * *}$} \\
\hline & $B$ & 51 (89.5) & $6(10.5)$ & & \\
\hline & $\mathrm{C}$ & $3(75.0)$ & $1(25.0)$ & & \\
\hline \multirow{2}{*}{ IV } & A & $6(60.0)$ & $4(40.0)$ & \multirow{2}{*}{$\begin{array}{l}107 * * * \\
30 * *\end{array}$} & \multirow{2}{*}{$\mathrm{X}^{2}=11.43^{* * *}(\mathrm{p}<0.001)$} \\
\hline & B & $24(80.0)$ & $6(20.0)$ & & \\
\hline
\end{tabular}


Table 16 Change of renal function of each group

\begin{tabular}{|c|c|c|c|c|c|c|}
\hline \multirow[b]{2}{*}{ Grade } & \multirow[b]{2}{*}{ Group } & \multicolumn{3}{|c|}{ Change of renal function } & \multirow[b]{2}{*}{ Total } & \multirow[b]{2}{*}{ Test } \\
\hline & & $\begin{array}{c}\text { Improved } \\
(\%)\end{array}$ & $\begin{array}{c}\text { Unchanged } \\
(\%)\end{array}$ & \begin{tabular}{|c} 
Deteriolated \\
$(\%)$
\end{tabular} & & \\
\hline \multirow{3}{*}{ I } & A & $3(30.0)$ & $6(60.0)$ & $1(100)$ & 10 & \multirow{3}{*}{$\begin{array}{c}\mathrm{H}=5661^{\mathrm{NS}} \\
(\mathrm{p}<01)\end{array}$} \\
\hline & B & $1(167)$ & $1(16.7)$ & $4(667)$ & 6 & \\
\hline & $\mathrm{C}$ & & & $1(100.0)$ & 1 & \\
\hline \multirow{3}{*}{ II } & A & $3(120)$ & $17(68.0)$ & $5(200)$ & 25 & \multirow{3}{*}{$\mathrm{H}=3751^{\mathrm{NS}}$} \\
\hline & B & $10(385)$ & $13(500)$ & $3(115)$ & 26 & \\
\hline & $\mathrm{C}$ & & $1(1000)$ & & 1 & \\
\hline \multirow{3}{*}{$\mathbb{I I I}$} & A & $2(154)$ & $8(615)$ & $3(231)$ & 13 & \multirow{3}{*}{$\mathrm{H}=2802^{\mathrm{NS}}$} \\
\hline & B & $16(471)$ & $14(412)$ & $4(118)$ & 34 & \\
\hline & $\mathrm{C}$ & $2(667)$ & & $1(333)$ & 3 & \\
\hline \multirow{2}{*}{ IV } & A & $1(125)$ & $6(750)$ & $1(125)$ & 8 & \multirow{2}{*}{$Z_{o}=0755^{\mathrm{NS}}$} \\
\hline & B & $6(375)$ & $8(50.0)$ & $2(125)$ & 16 & \\
\hline
\end{tabular}

Table 17 Morphological change of pyelogram of each group

\begin{tabular}{|c|c|c|c|c|c|c|}
\hline \multirow[b]{2}{*}{ Grade } & \multirow[b]{2}{*}{ Group } & \multicolumn{3}{|c|}{ Change of pyelographic forms } & \multirow[b]{2}{*}{ Total } & \multirow[b]{2}{*}{ Test } \\
\hline & & $\begin{array}{l}\text { Improved } \\
(\mathscr{6})\end{array}$ & $\begin{array}{l}\text { Unchanged } \\
(\mathscr{C})\end{array}$ & $\begin{array}{c}\text { Deteriolated } \\
(\mathscr{6})\end{array}$ & & \\
\hline \multirow{3}{*}{ I } & A & $5(185)$ & $19(704)$ & $3(11.1)$ & 27 & \multirow{3}{*}{$\mathrm{H}=1540^{\mathrm{NS}}$} \\
\hline & B & $2(200)$ & $5(500)$ & $3(30.0)$ & 10 & \\
\hline & C & $1(50.0)$ & $1(500)$ & & 2 & \\
\hline \multirow{3}{*}{ II } & A & $16(152)$ & 77 (73 3) & $12(114)$ & 105 & \multirow{3}{*}{$\mathrm{H}=1922^{\mathrm{N}}$} \\
\hline & B & $22(28.2)$ & $45(577)$ & $11(141)$ & 78 & \\
\hline & C & $1(20.0)$ & $4(800)$ & & 5 & \\
\hline \multirow{3}{*}{ III } & A & $6(98)$ & $50(820)$ & $5(82)$ & 61 & \multirow{3}{*}{$\begin{array}{l}\mathrm{H}=8742^{*} \\
(\mathrm{p}<0\end{array}$} \\
\hline & B & $28(329)$ & $51(600)$ & $5(59)$ & 85 & \\
\hline & t & $2(500)$ & $2(500)$ & & 4 & \\
\hline \multirow{2}{*}{ N } & A & $4(267)$ & $11(733)$ & & 15 & \multirow{2}{*}{$Z=1534^{\mathrm{NS}}$} \\
\hline & B & $18(462)$ & $20(513)$ & $1(26)$ & 39 & \\
\hline
\end{tabular}

ii）尿所見：蛋白，白血球数などについて検討してみ たが、とくに差を認めなからた。

c）腎機能, 腎形態の 推移：IVP の所見によつて, 治療が与えた影響について調查した。治療の前後で完全 な検查が行なわれた症例が少ない。また，形態の変化に 限りDIP の所見をむ採用したため，腎機能の調查例よ りも多くなつている.

i ) 腎機能: Grade II 〜IVでB群の改善率が良いが, 推計学的な差はみられなかつた (Table 16). Grade I にはB群が少ないが， 6 例中 4 例 $(66.7 \%)$ が悪化して いることは注目される。軽度なVUR に対する手術につ いて，1つの警告的資料として受取ることができよう。

ii）腎形態：Grade III に执いてB 群の改善率が A 群よ りも有意に $(\mathrm{p}<0.05)$ 良かつた (Table 17).な扮推計 学的な差は見なかつたが，ここでも Grade Iで， B 群
Table 18 Analysis of reflux-eliminated cases on chemotherapy group

\begin{tabular}{c|c|c|c|c|c|c}
\hline \multirow{2}{*}{ Sex } & \multirow{2}{*}{ Age } & \multicolumn{4}{|c|}{ Grade of VUR } & \multirow{2}{*}{ Total } \\
\cline { 3 - 7 } & & I & II & III & IV & \\
\hline \multirow{3}{*}{ Male } & $<10$ & 2 & 11 & 0 & 1 & 14 \\
\cline { 2 - 7 } & $>11$ & 2 & 1 & 0 & 0 & 3 \\
\hline \multirow{3}{*}{ Female } & $<10$ & 6 & 12 & 6 & 0 & 24 \\
\cline { 2 - 7 } & $>11$ & 11 & 6 & 0 & 0 & 17 \\
\hline
\end{tabular}

に30\%の悪化例が認められた。

d) 化学療法群 (A群) 飞招けるVUR 消失例の分 析 :

i ) 年齢・性：VUR 消失例 (両側 VUR は両側消失 をもつて消失例とした）と非消失例とを比較したとこ ろ，消失例は若年層に偏る傾向を示した。しかし， Mann-Whitney の検定では有意差にはならなかつた。

次に，消失例について VUR の程度に分けて検討し た. 10 歳を境に 2 群に分けると男女共殆んど II 度以下の 症例であり，正度以上で消失したものは，すべて10歳以 下の症例であつた (Table 18).

ii ) 化学療法の施行期間との関係：施行期間による差 の有無につき検討した．6 カ月以内の症例では約33\%，

1 年末満では半数が消失していた. しかし推計学的に検 索したが，有意差はなかつた。

e）手術群に持ける分析：

i ) VUR の消長: 逆流防止手術の術式別の成績を一 括表示した (Table 19). 失敗例から非消失率を算定し， 成績の良い順にあげると，Politano-Leadbetter 原法 (02), Paquin with cuff 法 (11), Politano-Leadbetter

Table 19 Results of antireflux surgeries

\begin{tabular}{c|c|c|c|r|c}
\hline Procedure & Eliminated & Unchanged & Unknown & Total & $\begin{array}{l}\text { Unchanged } \\
\text { rate }\end{array}$ \\
\hline 01 & 2 & 1 & & 3 & $333 \%$ \\
\hline 02 & 59 & 0 & & 59 & \\
\hline 03 & 2 & 2 & & 4 & 50.0 \\
\hline 04 & 3 & 0 & & 0 & \\
\hline 05 & 2 & 0 & & 2 & \\
\hline 07 & 42 & 12 & 4 & 58 & 222 \\
\hline 08 & 10 & 4 & 1 & 15 & 28.6 \\
\hline 11 & 44 & 3 & 2 & 49 & 64 \\
\hline 22 & 5 & 1 & & 6 & 16.7 \\
\hline 33 & 60 & 6 & & 66 & 91 \\
\hline Total & 229 & 29 & 7 & 265 & 10.9 \\
\hline
\end{tabular}

$\begin{array}{lll}02 \text { VS } 07 & p<0.01,02 \text { VS } 08 & p<005 \\ 02+33 \text { VS } 07 & p<0.05\end{array}$ 
変法 (33)，Lich-Gregoir 法 (07) となる. 推計学的に は Politano-Leadbetter 原法 (02) と Lich-Gregoir 法 (07), Hutch I法 (08) の間で，また, Politano-Leadbetter变法（33）と原法（02）とをあわせた場合, LichGregoir 法 (07) との間沈 $5 \%$ 以下の危険率で有意差を 見た。しか飞，全例で VUR の消失をみた PolitanoLeadbetter 原法には，腎機能の廃絶した症例が 1 例存在 していた。これは，VUR の消失が，まれに，手術の失 敗 (狭窄形成)によりるたらされることのあることを示 唆している.

ii ) VUR 非消失例の年值と術式の関係：VUR を消失 せしめ得なかつた症例を，主な術式別に，また，年龄別 飞 Table 20亿示した (Table 20).これによれば, LichGregir 法（07）では10例の 非消失例中 8 例 が 11 歳以上

Table 20 Analysis of the unchanged or deteriorated cases after antireflux surgeries

\begin{tabular}{c|c|c|c|c|c}
\hline \multirow{2}{*}{ Procedure } & \multicolumn{4}{|c|}{ Age } & \multirow{2}{*}{ Total } \\
\cline { 2 - 6 } & $0 \sim 6$ & $7 \sim 10$ & $11 \sim 20$ & $21 \sim$ & \\
\hline 07 & 1 & 1 & $1+1^{*}$ & 6 & 10 \\
\hline 08 & 2 & 1 & & 1 & 4 \\
\hline 11 & & & & $1+1^{*}$ & 2 \\
\hline 33 & $2+1^{*}$ & 1 & & 1 & 5 \\
\hline
\end{tabular}

cf. * bilateral cases

で，このらち 6 例が 21 歳以上であり，本術式の成人への 適用に，特に問題があるとい方よう。一方，Hutch I 法 (08) と Politano-Leadbetter 変法（33）では10歳以 下に失敗例が多いといら結果であつた。

iii) 発熱 : VUR の消失率と発熱の消長とは，注ほ一 致した傾向であつた。

iv）腎機能と腎形態：

（1）腎機能：主な術式について検討しだ。Table 21-1 飞見るごとく，Hutch I 法（08）に悪化した例が 多く, Politano-Leadbetter 変法 (33) では23.5\%, LichGregoir 法（07）は20\%が悪化していた (Table 21ー1). ここでも Politano-Leadbetter 原法 (02) が比較的良い 成績を示していたが, 推計学的には差を認めなかつた。

（2）腎形態：Table 21-2のごとく Lich-Gregoir 法 (08)で悪化したものが26.1\%と多からたが, KruskalWallis の検定で有意な差は出なかつた (Table 21-2).

\section{考 按}

今回の共同研究では各機関の保有されている症例を，
Table 21 Change of the renal function and pyelographic forms after antireflux surgeries

1) Renal function

\begin{tabular}{c|c|c|c|c}
\hline Procedure & $\begin{array}{c}\text { Improved } \\
(\%)\end{array}$ & $\begin{array}{c}\text { Unchanged } \\
(\%)\end{array}$ & $\begin{array}{c}\text { Deteriolated } \\
(\%)\end{array}$ & Total \\
\hline 02 & $7(46.7)$ & $7(46.7)$ & $1(6.7)$ & 15 \\
\hline 07 & $5(50.0)$ & $3(30.0)$ & $2(20.0)$ & 10 \\
\hline 08 & $3(42.9)$ & $1(14.3)$ & $3(42.9)$ & 7 \\
\hline 11 & $5(31.3)$ & $8(50.0)$ & $3(18.8)$ & 16 \\
\hline 33 & $2(11.8)$ & $11(64.7)$ & $4(23.5)$ & 17 \\
\hline
\end{tabular}

$\mathrm{H}=5.388^{\mathrm{NS}}$

2) Pyelographic forms

\begin{tabular}{c|c|c|c|c}
\hline Procedure & $\begin{array}{c}\text { Improved } \\
(\%)\end{array}$ & $\begin{array}{c}\text { Unchanged } \\
(\%)\end{array}$ & $\begin{array}{c}\text { Deteriolated } \\
(\%)\end{array}$ & Total \\
\hline 02 & $16(36.4)$ & $25(56.8)$ & $3(6.8)$ & 44 \\
\hline 07 & $5(21.8)$ & $12(52.2)$ & $6(26.1)$ & 23 \\
\hline 08 & $2(22.2)$ & $4(44.4)$ & $3(33.3)$ & 9 \\
\hline 11 & $8(28.6)$ & $19(67.9)$ & $1(3.6)$ & 28 \\
\hline 33 & $7(21.2)$ & $23(69.7)$ & $3(9.1)$ & 33 \\
\hline
\end{tabular}

$\mathrm{H}=5.934^{\mathrm{NS}}$

期間を区切ることなく，すべて対象にしたこともあつ て，内外のこの種の研究報告に比べても，可成り多数と いえる primary VUR を解析することができた。これ らの症例は，撖密な 基準に 基づいて 調查票の記入がな された上に，集計時の再調查が 実施されているので， primary VUR 以外は完全に除外されていると考えてょ い.

性別：統計では女子が男子の約 3 倍を占めていて, 若 年層注ど性差の減少傾向が 見られ，10歳以下では1.3 2 倍程度であつた。 Lenaghan 等1)は子供の primary VUR 102例を報告し，性比は1：1.9と我々と注ぼ同じ 值であつたが，2 歳以下では男子が多いと述べている。 最近の primary VUR で100例以上の報告は; 殆んと子 供に関するものであり, Dwoskin and Perlmutter ${ }^{2)}$ (281 例) は $1: 5.5$, Willscher 等 ${ }^{3)}$ (223例) は $1: 3.6$, Arap 等4) (180例) は $1: 3.4$, Amar and Singer ${ }^{5)}$ (280 例) は1:3.1, Scott ${ }^{6)}$ (262例) は1:3.0と, すべて 女子に多いと報告して挌り，いずれも我々の統計よりも 性差が大きかつた。

一方, 大人の 統計は少なく, Lipsky and Chisholm ${ }^{7)}$ がわずが61例を集計しているが，1：4 と我々の集計 よりも男子が多い，ちなみに，我々の統計では，20歳代 で1：26，31歳以上では 1：7 と圧倒的に女子が多から 
た.

UTI の既往：Arap 等"4) $98 \%$ が既往を有していたと 報告しているが, Dwoskin and Perlmutter ${ }^{2)}$ は60\%にす ぎなかつたと報告している。このように報告によつて大 きな差が見られたが，Lipskey and Chisholm ${ }^{7)}$ の85.2\% のごとく, 我々の今回の統計とほぼ同率の值を報告して いるものもある．性別では他に報告を見なからたが， 我々の集計では男子で76\%，女子で $88.1 \%$ と女子が有意 に高頻度であり, この差を解析した結果, 成人の男女で 生じたるの子判明した，女子に括ける妊娠や出産に伴つ た UTI の発症が，本症の成因ないし発現に大きな役割 を果していると考えられる。

VUR の分類とその分布：今回はVUR をI〜IV度 の4段階に分けたのち，I，II度はIVP または DIP の所見によつて, さらに, $\mathrm{A}, \mathrm{B} の 2$ 群に分類した。 Dwoskin and Perlmutter ${ }^{2)}$ も多少異なる所もあるが， ほ 添同じ分類を行つている。このほか手術の適応例とそれ 以外の 2 群に分ける方法, 尿管の太さによつて分類する ものなどがあり，統一されたものはない，従つて文献的 に VUR の分布を比較することはむつかしいが，原ぽ 分類方法が似通つている Dwoskin and Perlmutter ${ }^{2)} に$ よれば，我々の統計と同じくGrade II の症例が多い傾 向を示していた。しかし，彼等の統計では74.7\%と3/4 を占めているのに対し，我々の集計では $54.2 \%$ 止つ た.一方，Grade III，IVは19.9\%と我々の $30.8 \%$ よも 10\%以上少なかつた。

両側の VUR は今回の集計によると $44.5 \%$ と, Amar and Singer ${ }^{5)}$ の $44.3 \%$ と注湆同率であつたが，その他の 文献でもつと高率の報告もある. 我々の統計で左右の相 関を調べてみると，相関係数は $\gamma_{\mathrm{s}}=0.630$ と非常に高い 值を示した。これは, primary VUR には両側性が多く， さらにその場合, 左右同程度の VUR が存在する可能性 が高いことを示唆しているものといえる。

VUR の程度と腎機能ならびに腎形態との関係：今回 の解析結果では, VUR と腎機能との相関係数は, わず か $\gamma_{s}=0.258$ にすぎず, やや相関ありの程度と判定され た. 腎形態との相関は $\gamma_{s}=0.662$ と極めて高い值を示し ていた。一般に VURの高度なるのは腎の形態的変化 を伴うことが多いが，今回は pyelonephritic scarring に ついて検索は実施しなかつた. Dwoskin and Perlmut$\mathrm{er}^{2)}$ はVUR の高度なもの汪ど scar が増すことを報告 し, 形態的変化の発生頻度が增加することを見ている。 治療法別の VUR 消失率: 今回の集計では無治療群
（C群）は，わずか39例であつたが，約70\%に VURの 消失が認められた. Stephens and Lenaghan ${ }^{8)}$ は59尿管 の観察で19尿管，32.2\%が消失したとし，また O'Donnell 等9) は19例で僅か 1 例， $5.3 \%$ の消失に此つたと報 告している，我々の統計では高率に消失が見られたが， 消失例の殆んぞが若年男子で, Grade II A 以下の症例で 方，しかも，UTI の既往のない軽症例を 3 年以上の 長期にわたつて観察したものであつた.

一方， A 群は C 群よりもやや高度の VUR が含柰れ ているとはい党, 平均 $27.3 \%$ の消失率に止つている。程 度別にみると，Grade I が43.7\%，Grade II は25.6\%， Grade III $15.4 \%$, Grade IVはわずかに13.3\%となつて 招り，VUR が高度なるのほど消失率が隇少している。

Table 22 Results in comparative series of conservative treatment

\begin{tabular}{|c|c|c|c|}
\hline$\dot{.}$ & $\begin{array}{c}\text { Patients } \\
\text { (Ureters) }\end{array}$ & Tratment & Elimination of reflux \\
\hline $\begin{array}{l}\text { Stephens \& Lenaghan } \\
\text { (1962) }\end{array}$ & $\begin{array}{c}34 \\
(59) \\
\end{array}$ & no treatment & $19(3229)$ \\
\hline $\begin{array}{l}\text { Fisher \& Darling }{ }^{101} \\
(1967)\end{array}$ & 50 & $\begin{array}{l}\text { long term } \\
\text { chemotherapy }\end{array}$ & $24(480 \%)$ \\
\hline \multirow{2}{*}{$\begin{array}{l}\text { O' Donnell et al. }{ }^{9)} \\
(1969)\end{array}$} & \multirow[t]{2}{*}{98} & no treatment & $1 / 19(53 \%)$ \\
\hline & & $\begin{array}{l}\text { long term } \\
\text { chemotherapy }\end{array}$ & $10 / 79(127 \%)$ \\
\hline $\begin{array}{l}\text { Dwoskin \& Perlmutter }{ }^{21} \\
\quad(1973)\end{array}$ & 114 & $\begin{array}{l}\text { long term } \\
\text { chemotherapy }\end{array}$ & $\left.\begin{array}{ll}\mathrm{I} & 715 \% \\
\mathrm{II}_{\mathrm{A}} & 48.0 \% \\
\mathrm{I}_{\mathrm{B}} & 366 \%\end{array}\right\} 490 \%$ \\
\hline \multirow[t]{4}{*}{$\begin{array}{l}\text { Lenaghan et al. }{ }^{11} \\
(1976)\end{array}$} & \multirow[t]{4}{*}{102} & \multirow[t]{4}{*}{$\begin{array}{l}\text { intermittent } \\
\text { chemotherapy }\end{array}$} & $\begin{array}{l}\text { normal ureter } \\
65 / 98(6639)\end{array}$ \\
\hline & & & $\begin{array}{c}\text { mod enlarged ureter } \\
15 / 48(313 \%)\end{array}$ \\
\hline & & & $\begin{array}{c}\text { gros enlarged ureter } \\
3 / 21(143 \%) \\
\end{array}$ \\
\hline & & & \begin{tabular}{|l} 
total \\
$\quad 43 / 102(422 \%)$ \\
\end{tabular} \\
\hline $\begin{array}{l}\text { Scott }{ }^{6} \\
(1977)\end{array}$ & 54 & $\begin{array}{l}\text { intermittent } \\
\text { chemotherapy }\end{array}$ & $34 / 54(630 \%)$ \\
\hline $\begin{array}{l}\text { Edwars et al. }{ }^{11} \\
(1977)\end{array}$ & $\begin{array}{c}75 \\
(121)\end{array}$ & $\begin{array}{l}\text { intermittent } \\
\text { chemotherapy }\end{array}$ & $\begin{cases}95 / 121(785 \%) \\
\text { I } & 89 \% \\
\text { II } & 86 \% \\
\text { III } & 83 \% \\
\text { IV } & 41 \%\end{cases}$ \\
\hline
\end{tabular}

文献的には表示するごとく，最低は O'Donnell 等9) の $12.7 \%$ であつたが，Lenaghan 等 ${ }^{11}$ 平均 $42 \%$ と述べ， この消失率は尿管の太さによつて変るとしている.すな わち，1cm 以下の 正常尿管は $66 \% ， 1 \sim 2 \mathrm{~cm}$ の中等度 拨張では $33 \%, 2 \mathrm{~cm}$ 以上の拡張を見るものでは $14 \%$ の 消失である．また小さい子供汪ど早く消失するとして いるが，我なの統計でも㴗济同じ傾向を認めた（Table 22).

消失をでの期間については， $\operatorname{Scott}^{6)}$ によれば，2/3の 消失例の内， $46 \%$ の症例では，消失に 3 年以上を要した とのことである。一方 Dwoskin and Perlmutter ${ }^{2}$ によれ ば， I A〜II B の軽症 VUR が99\%を占めている114例の 
Table 23 Results in comparative series of antireflux surgery

\begin{tabular}{|c|c|c|c|c|}
\hline & $\begin{array}{c}\text { Patients } \\
\text { (Ureters) }\end{array}$ & Procedures & $\begin{array}{l}\text { Unchanged } \\
\text { Cases }\end{array}$ & Complications \\
\hline $\begin{array}{c}\text { Politano } \\
(1963)\end{array}$ & $\begin{array}{c}100 \\
(162)\end{array}$ & Politano-Leadbetter & 0 & $\begin{array}{r}\text { Obstruction } \\
5(5.0 \%) \\
\end{array}$ \\
\hline $\begin{array}{c}\text { Price et al. }{ }^{18)} \\
(1970)\end{array}$ & $\begin{array}{l}102 \\
(191)\end{array}$ & Politano-Leadbetter & 0 & $\begin{array}{c}\text { Renal failure } \\
6(3.1 \%)\end{array}$ \\
\hline $\begin{array}{l}\text { Arap et al. }{ }^{4)} \\
(1971)\end{array}$ & $\begin{array}{c}180 \\
(306)\end{array}$ & Lich-Gregoir & 4 cases & $\begin{array}{l}\text { Obstrction } \\
5(1.6 \%) \\
\end{array}$ \\
\hline $\begin{array}{l}\text { Garrett \& Schlueter }{ }^{16)} \\
\quad(1973)\end{array}$ & 140 & $\begin{array}{l}\text { Politano- Leadbetter } \\
\text { (117 patients) } \\
\text { Grenn-Anderson } \\
\text { (15 patients) }\end{array}$ & 0 & $\begin{array}{l}\text { Excessive short- term } \\
\text { dilatation } 10(7.1 \%) \\
\text { Continued urographic } \\
\text { deterioration } \\
22(15.7 \%) \\
\text { Functional deterioration } \\
11(7.9 \%) \\
\text { Renal contraction } \\
15(10.7 \%) \\
\end{array}$ \\
\hline $\begin{array}{l}\text { Woodard \& Keats }{ }^{13)} \\
(1973)\end{array}$ & $\begin{array}{l}126 \\
(217)\end{array}$ & Paquin & $\begin{array}{l}3 \text { ureters } \\
(1.4 \%)\end{array}$ & Obstruction $6(2.8 \%)$ \\
\hline $\begin{array}{c}\text { Hendren }^{15)} \\
(1974)\end{array}$ & 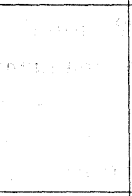 & \begin{tabular}{|l|} 
Lich-Grgoir \\
(43 uertrs) \\
Intravesical \\
Politano- Leadbetter \\
( 875 uertrs) \\
Combined P- $\mathrm{L}$ \\
(121 uerters) \\
\end{tabular} & $18 / 43(42.2 \%)$ & $\begin{array}{l}\text { Obstruction } 7(16.3 \%) \\
\text { Complications } 3.0 \% \\
\text { Complications } 3.0 \%\end{array}$ \\
\hline $\begin{array}{l}\text { Willsher et al. }{ }^{31} \\
(1976)\end{array}$ & $\begin{array}{c}223 \\
(342)\end{array}$ & Politano-Leadbetter & 0 & Obstruction $4(1.2 \%)$ \\
\hline$\underset{(1977)}{\text { Marshall et al. }{ }^{12)}}$ & 3527 & & 4 cases & $\begin{array}{lr}\text { Infection } & 59 \% \\
\text { Inframmatory } & \text { change } \\
\text { on IVP } & 4 \% \\
\text { Obstruction } & 4 \% \\
\text { Renal failure } & 2 \% \\
\text { Miscellaneous } & 1 \% \\
\end{array}$ \\
\hline $\begin{array}{c}\text { Hampel et al. }{ }^{14)} \\
(1977)\end{array}$ & $\begin{array}{l}126 \\
(217)\end{array}$ & Paquin & $\begin{array}{l}3 \text { ureters } \\
(1.4 \%)\end{array}$ & $\begin{array}{l}\text { Obstruction } \begin{array}{c}6 \text { ureters } \\
(2.8 \%)\end{array} \\
\end{array}$ \\
\hline
\end{tabular}

少女について, コンピューターによつて解析を施行し, Grade I で71.5\%, Grade II A で48\%, II в で36.6\%, 平均で $49 \%$ が消失したが，2 年以内の消失は65\%，3年 以内に $78 \%$ が消失したと報告している。この成績は， 我々の統計に比べて消失率が高いが，対象が主に軽症の VUR の少女であつたことも考虑する必要がある。一 方, Edwards 等 ${ }^{11)}$ は間歇的長期化学療法を行い, Grade IIIまでの VUR は83\%以上も消失し, Grade IVです41 \%の消失をみたと述べている，彼等は年柃，性別とは無 関係に，2 年毎に20～30\%宛消失するが，これは膀胱の 発育によるものと述べている．前述のごとくVUR の 分類基準が異なることもあつて，同一レベルでの比較が 困難であるが，それにしても，この報告に和ける消失率 は異常に高いといえる(Table 22).なお，今回の統計 では化学療法施行例の 増悪例については調べなかつた が, Dwoskin and Perlmutter ${ }^{2)}$ は3.2\%と報告して扔り， 今後の重要な調査課題といえよう。

VUR に対する手術の成績をみるる, 今回の統計で
は, Politano-Leadbetter 原法を施行された症例はすべて VUR の消失をみており，この点では他の術式に比して すぐれた方法といえる。しかし，消失率がすなわら成功 率ではないことは先に述べた通りで，合併症の有無，“腎 機能の消長も判定基準の重要な指標である。これらを考 慮に入れた上で，最近の文献より，主な逆流防止手術 の成績と合併症 とを Table 23にまとめてみた（Table 23).

これでみても，Politano-Leadbetter 法は, Marschall 等 ${ }^{12)}$ の報告を除き, VUR の消失率が高い. 彼等の報告 では，3,527例と析外れの多数例の内，消失しなかつた 症例がわずかに 4 例， $0.11 \%$ であり，本法が VUR 防止 手術としては，汪活完壁な手術方法であることを示唆し ている、しかし，な扣施行にあたつては狭窄発生の防 止に万全の注意が必要であろう. 一方, Paquin 法も Woodard and Keats ${ }^{13)}$ によると成績がよく，わずかに 1.4\%の非消失率である. Lich-Gregoir 法について Arap 等 ${ }^{4)}$ は $4 \%$, Hampel 等 ${ }^{14)}$ は $6 \%$ に逆流が消失しなかつ 
たと報告している． Hendren ${ }^{15)}$ は1,039尿管に対する VUR 防止手術の経験を報告しているが，はじめの 3 年 間 Lich-Gregoir 法を43尿管に 施行したところ，44.2\% に逆流の再発を，また，16.3\%の尿管閉塞を生じた。そ こで, Politano-Leadbetter 法に切り換えたところ, 原法 もCombined 法も共に成績が向上し，合併症が $3 \%$ に 減じたと述べている。

合併症としては，この尿管の閉塞の外，難治性感染 症，尿管壊死，腎機能不全などが挙げられる. 我々の集 計では，とくに合併症を記入する欄を設けなかつたた め，わずか $1.7 \%$ の尿管閉塞を見つけたに止まつたが, 文献的には1.5〜 5\% 報告されている334122 18). Hendren ${ }^{15)}$ は Politano-Leadbetter 法による失敗例について 原因を追及し, 粘膜下トンネル形成不充分, 再吻合部尿 管の属曲, 線維化などを挙げている. Garett and Schlu$\operatorname{eter}^{16)}$ は失敗の主な原因は 3 歳以下の手術, UTI のあ る時期での手術，手技上の失敗にあると述べている。し かし; Willsher 等 ${ }^{3)}$ は同じ逆流防止手術を平均3.4歳の 小児に実施して，尿管閉塞はわずかに $1.2 \%$ に止つたと 報告しているので，技術面での進歩さえあれば，特に年 秢は問題にならぬと思われる。

な特，今回の統計に和ける VUR 非消失例について 分析してみると， Lich-Gregoir 法は成人が多く, Hutch I法と, Politano-Leadbetter 法では逆に10歳以下の症例 であつたが，術式を選択する上で，一つの示唆とみるこ ともできよう。

\section{結語}

昭和 49,50 年の 2 年間, 13 機間によつて, 文部省科学 研究助成金に上る総合研究「膀脱尿管逆流現象に関する 研究」を行つたが，との共同研究として， primary VUR の retrospective な調查を取り上げた。集計された症例 実数は494例，6 カ月以上にわたる 化学療法が奏効せず に, 途中で手術療法湾更した症例は 2 例として登録す るようにしたので，延数は536例となつた．これをコン ピューターで推計学的に解析し, 次の結果を得た。

1.494例の性別は, 男子130例, 女子364例で, 男女 比は $1 ： 2.8$ であつた。年龄別では, 20歳代が $1: 26$ と 最も差があり, 若年層ほど性差が少なくなる傾向が認め られた。

2. 尿路感染の既往を有するものは，男子 $76 \%$ ，女子 88.1\%に及んでいたが，男女差は成人で生じたもので， 女子に拈ける性活動を契機とした発症を反映したものと 解积される。
3.VUR は 6 段階に分類したが， I A 〜II в の軽症例 が約70\%，正度までが90\%以上を占めていた。 primary VUR 涼度な逆流が少ないことを示しているといえる。 な拈，両側 VUR は $44.5 \%$ であ，男子の両側例飞高度 なVUR が多かつた。

4. VUR の程度と現症との間には，明らかな関係は 存在しなかつた.

5. VUR の程度と腎機能の関係は，腎盂撮影を利用 した判定でみると，腎機能との相関係数は $\gamma_{\mathrm{s}}=0.258$ に 止まつていた.

6. 536例を治療法別に分けると，化学療法施行群 (A 群) が297例 (55.4\%) と最も多く, 次いで手術群 (B 群) 194例 (36.2\%), 無治療経過観察群 (C 群) 39 例 $(9.3 \%)$ ，その他（D群）6例 (1.1\%) の順になつ ている.

7. D群を除いて治療法別に背景調査を行つたＡ群 は年少女子の比較的軽症の症例が多く, B 群は UTI の 既往を有する III 度以上の症例で，発熱，腰痛，蛋白尿を 有するものが多い，一方，C群はUTI の既往が少ない 若年の軽度 VUR 症例が主体をなしていた。

8. 治療法別に VUR 消失率を比較すると, 各 Grade とも B 群が有意に成績が良い，とくに，林度以上の高度 な VUR では，B群の消失率が圧倒的に高く，A群では 13〜15\%の消失に止まつている.C群は70\%と高い消失 率を示していたが, 症例数が少く, 又年齢は $\mathrm{A}$ 群に比し より若年層にかたより，既往のUTI 発症頻度も有意に 低率であることから，比較上の意義づけは出来る。

9. 治療法別の治療後の発熱調查では，I 度は各群間 の差を認めなかつたが， II 度以上ではB 群の改善率が明 らか高く，注添 VUR の消長と一致する成績であつ た.

10.治療による腎機能ならびに腎形態の変化について 調査した．腎機能では推計学的に有意差が得られなかつ たが，腎形態では， III度のB 群に改善率が高かつた。し かし，I 度に执いてはB 群に腎機能，形態共に悪化した 症例があり，軽度の VUR に対するVUR 防止手術の 適用について，1つの警告的資料と受取つた。

11. 化学療法群の VUR 消失例を分析したところ, 男女共汪とんど II 度以下の症例であり， III度以上の消失 例はすべて 10 歳以下であつた。約半数が 1 年以内に消失 しているが，推計学的には，治療期間と特別な関係を認 めなかつた。

12. VUR 防止手術は, combined Politano-Leadbetter 
法が66例 $(23.1 \%)$ と最も多く，同原法59例 $(20.6 \%)$ がこれに次ぎ，以下 Lich-Gregoir 法58例! (20.2\%), Paquin with cuff 法49例 $(17.1 \%)$, Hutch I 法 17例 (5.9\%) が主なるのであつた。

13. VURの消失例からみた手術成績は, PolitanoLeadbetter 原法が $100 \%$ と最も良く, Paquin with cuff 法 $94.6 \%$, Politano-Leadbetter 変法90.9\%, Lich-Gregoir 法77.8\%の順になつていた.

失敗例の分析によると, Politano-Leadbetter 変法と Hutch I 法がほとんど10歳以下の症例であるのに対し て，Lich-Gregoir 法は成人女子に多いことが注目され た。

14. 発熱から見た各種手術法の追跡結果は, VUR の 消失率と一致していた.

15. 腎機能，腎形態からみた術式別の検討では, Politano-Leadbetter 原法が最も成績がよく，例数が少な いが，Hutch I 法に機能の悪化したものが多かつた。な 括 Politano-Leadbetter 変法, Lich-Gregoir 法でも約20 \%の悪化した症例が見られた。

本研究は文部省科学研究助成金, 総合研究 $\mathrm{A}$ の助成に より行われた。

本論文の要旨は第65回日本泌尿器科学会総会に打いて 「総合研究班報告」文部省科学研究助成金, 総合研究 VUR 研究班に打忊る非閉塞性 VUR の追跡調查成績に ついてと題しで報告した。

本稿を終えるにあたり，推計学的な解析と御助言を頂 いた武田薬品工業株式会社企画開発本部開発部楠正試験 解析室長，ならびに小里芳顕氏に深甚の謝意を表しま 于.

\section{文 献}

1) Lenaghan, D., Whitaker, J.G., Jensen, F. and Stephens, F.D.: The natural history of reflux and long-term effects of reflux on the kidney. J. Urol., 115, 728-730, 1976.

2) Dwoskin, J.Y. and Perlmutter, A.D.: Vesicoureteral reflux in children: A computerized review. J. Urol., 109, 888-890, 1973.

3) Willscher, M.K., Bauer, S.B., Zammuto, P.J. and Retik, A:B.: Infection of the urinary tract after anti-reflux surgery. J. Pediat., 89, 743746, 1976.

4) Arap, S., Cabral, A.D., DeCampos Freire, J.D., Gregoir, W. and Van Regemorter, G.: The extra-vesical antireflux plasty statistical analysis. Urol. Int., 26, 241-251, 1971.
5) Amar, A.D. and Singer, B.: Vesicoureteral reflux: A 10-year study of 280 patients. J. Urol., 109, 999-1001, 1973.

6) Scott, J.E.S.: The management of ureteric reflux in children. Brit. J. Urol., 49, 109-118, 1977.

7) Lipsky, H. and Chisholm, G.D.: Primary vesicoureteric reflux in adults. Brit. J. Urol., 43, 277-283, 1971.

8) Stephens, F.D. and Lenaghan, D.: The anatomical basis and dynamics of vesicoureteral reflux. J. Urol., 87, 669-680, 1962.

9) O'Donnell, B., Maloney, M.A. and Lynch, V.: Vesico-ureteric reflux in infants and children. Results of "supervision", chemotherapy and surgery. Brit. J. Urol., 41, 6-13, 1969.

10) Fisher, J.H. and Darling, D.B.: The course of vesicoureteral reflux, associated with urinary tract infection in children. J. Pediat. Surg., 2, 221-226, 1967.

11) Edwards, D., Normand, I.C.S., Prescod, N. and Smellie, J.M.: Disappearance of vesicoureteric reflux during long-term prophylaxis of urinary tract infection in children. Brit. Med. J., 2, 285-288, 1977.

12) Marshall, S., Guthrie, T., Jeffs, R., Politano, V.A. and Lyon, R.P.: Ureterovesicoplasty: Selection of patients, incedence and avoidance of complications. A review of 3,527 cases. J. Urol., 118, 829-831, 1977.

13) Woodard, J.R. and Keats, G.: Ureteral reimplantation: Paquin's procedure after 12 years. J. Urol., 109, 891-894, 1973.

14) Hampel, N., Richter-Levin, D. and Gersh, I.: Extravesical repair of primary vesicoureteral reflux in children. J. Urol., 117, 355-357, 1977.

15) Hendren, W.H.: Reoperation for the failed ureteral reimplantation. J. Urol., 111, 403411, 1974.

16) Garett, R.A. and Schlueter, D.P.: Complications of antireflux operations: cause and management. J. Urol,, 109, 1002-1004, 1973.

17) Politano, V.A.: One hundred reimplantation and five years. J. Urol., 90, 696 -699, 1963.

18) Price, S.E. Jr., Johnson, S.H. III and Marshall, M. Jr.: Experience with ureteral reimplantation in the treatment of recurring urinary infection in childhood. J. Urol., 103, 485-490, 1970.

19）新島端夫：文部省科研総合研究 VUR 研究班に 和ける非閉塞性 VUR の追跡調查成績について。 日泌尿会誌，68，854-855, 1977 . 